\title{
Mapping and Analyzing the Volcano-Petrology and Tectono-Seismicity Characteristics Along the Syrian Rift - NW the Arabian Plate
}

\author{
Ahmad Bilal \\ Damascus University, \\ Syria
}

\section{Introduction}

The European and African continents are crossed by several N-S-trending rifts, all together major structural features at world scale. They include, from North to South, firstly the Oslo Permian rift (Norway), continued by the Neogene fracture system of Central-Southern Germany (Eifel, Rhine Graben), then the rift system of French massif Central and Rhone valley, ending finally with the great African rift, the major structure of this continent.

These major crustal fractures, extending down in the underlying mantle, have been active at different times, while always keeping the same approximate N-S direction. Periods of major activity are marked by extensive volcanism, with a distinct tendency to show younger ages southwards: Permian in Norway, Neogene in Germany, Neogene to subactual in France, actual (present-day) in Africa. These ages correspond mainly to the initial stage of riftforming, whereas more ancient accidents (e.g. Norway) could repeatedly play again, at each phase of crustal extension.

In direct continuity with the Dead Sea Fault, the Syrian rift links the rigid Arabian plate to the mobile ophiolite belt of Cyprus and Southern Turkey (Juteau 1974, Parrot 1977). It plays a very important role in the regional geodynamic structure. Its exact position, as well as the related fracture system, has been documented from the analysis of complete aerial photo coverage of the whole Syrian territory (Bilal and Ammar 2004).

Many partial works on the different aspects of this area: tectonics, geodynamics, volcanism, crustal and mantle rocks, and seismicity have been done. But a global synthetic on these aspects are given in this research, using new data in field and laboratory. The results either of my team at Damascus university, or either those of the scientific cooperation projects, from 1998 till now, with the teams of colleagues from the French universities: professors Jean Chorowicz, and Albert Jambon, from Pierre and Marie Curie university; professor Phillipe Huchon, from Ecole Normal Superior of Paris; professor Jacques Touret, from Ecole des Mines of Paris, and professor Jean Ives Cottin from the university Jean Monnet of SaintEtienne. In addition to international works indicated in the references list. While the global work, at the macro- scale, has been achieved, it still more works to do at the micro -scale: the detailed composition variations of the volcanic rocks, and their geologic process indication; the liaison between the different tectonic unities, and theirs liaison with the regional geotectonic; and the micro- seismic zonation in the country. 


\section{Geodynamic setting}

The Arabian plate has a roughly polygonal shape, inserted between the major African plate (including Nubian and Somalian ), to the East, and Eurasiatic and Indian plates, to the North. It is delimitated by the Red Sea in the South-West, the Aden gulf in the South, and the Zagros and Taurus chains in the North and North-East, respectively.

Geophysical investigations confirms the typical continental nature of this plate, with an average crust thickness of $40 \mathrm{Km}$, which changes, at the level of the Red Sea , to less than 15 $\mathrm{Km}$., on a distance of about $250 \mathrm{Km}$.(Al Damegh et al.2005).

The Arabian plate shows three types of active borders (Fig.1):

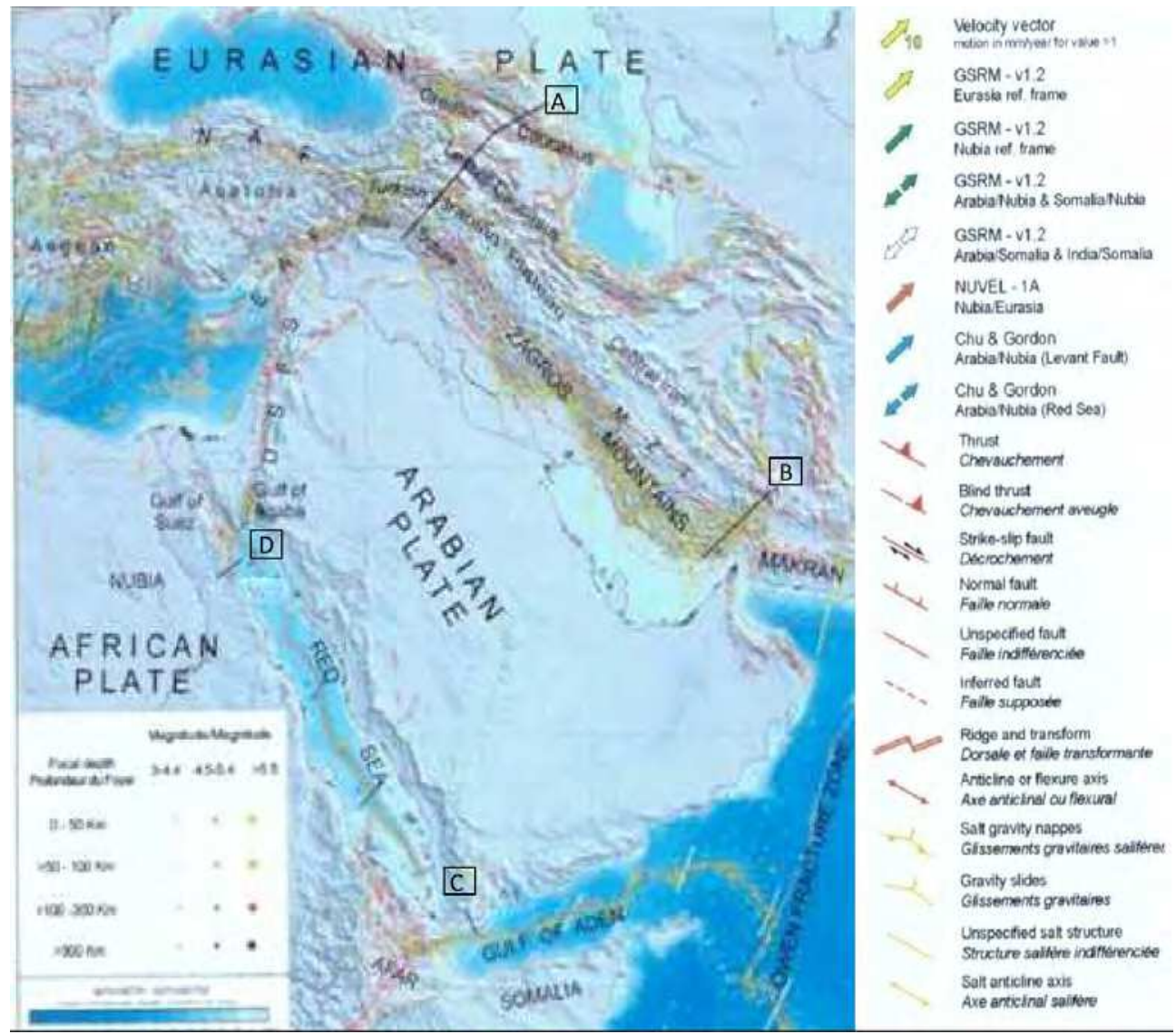

Fig. 1. Geodynamic framework of the Arab plate (Barrier et al. 2004).

- Convergent :it include the collision zone of Bitlis-Zagros (Fig.1,A,B) ,(Sosson et al 2005,Molinaro et al 2005,Agard et al.2006), the subduction Makran-Oman zone between 
Aurasia-Arabia, as well as the Anatolian fault at the north-west end of the Arabian plate(Cetin et al.2003).

- Divergent: the oceanic rifts (Arabia-Nubia), and the Aden gulf (Arabia-Somalia), (Fig.1, C, D),(Bosworth et al.2005)

- Transform: the senester faults of the Levant (Arabia-Nubia), to the West and the Dexter faults of Owen (Arabia-India), to the East (Barrier et al.2004).

The territory of syria corresponds to the NW corner of the Arabian plate. It is bordered by the Zagros Taurus collision zone, to the North, and the oceanic expansion zone, to the South. In the Western part of Syria, the rift structure, which corresponds to the northern part of the Dead Sea Fault Zone(DSFZ), is named the Levant fault, in continuity with the Red Sea rift zone.

\section{Interplate volcanism along the Syrian rift}

The Syrian rift is marked by an active interplate volcanism, occurring from Jurassic to present (Ponikarov 1967, Laws and Wilson 1997, Giannerini et al.1998). Volcanoes bring to the surface a number of mantle xenoliths, which provide essential information on the nature and composition of the underlying lithospheric mantle (Stein and Hofman 1992, Stein et al 1993, Sharkov et al.1993, Bilal and Touret 2001, Bilal and Sheleh 2004). Most important data are summarized below:

\subsection{Volcanism}

The occurrence of volcanic activity in its geotectonic context shows that this activity covers an important part of the surface of the Arabian plate: in Syria; in Jordan; and in Saudi Arabia (Fig.2). This volcanism covers the Mesozoic and Cenozoic times, but the major eruption is recent. It is distributed over three distinct regions (Mor 1993): (1) the Harrat Ash Shaam plateau; (2) the region from the Homs basalts to the Karasu valley; (3) the Arabian platform and the Southern part of the Bitlis belt (e.g.karacadage volcano).

The Harrat Ash Shaam basalt eruption occurred in three episodes: at 26-22 Ma.;1813Ma.; and 7to <0,5Ma.(Mor 1993, Ilani et al 2001). The Homs basalts are dated at 6,52,0Ma.(Mouty et al.1992,Sharkovet al.1994,1998,Butler et al.1997, Butler and Spencer 1999).In the Ghab basin area and east of it ,the age ranges from 2.0 to 1,1 Ma (Heiman et al 1998). In the Karasu valley and vicinity, the age vary from 1, 6 to 0, 05 Ma. (Capan et al.1987,Heiman et al.1998, Rojay et al 2001, Yurtmen et al 2002).

Summarizing, volcanism in Syria, started during Lias with magmatism associated to the ophiolites in the north of the territory (in the Baer et Bassit region), at the same time of volcanism in the southern of Turkey (Antalya et Hatay), or in the Mamonia complex in Cyprus (Robertson et al.1991).This volcanism is related to subvertical tension fractures caused by transcurent movement along the Syrian part (the Syrian rift)of the Dead Sea Fault Zone(DSFZ).It can be hypothetized that these fractures induced adiabatic partial melting in the lithosphere (Polat et al.1997,Adiyaman and Chorowwicz 2002,Chorowicz et al.2005).

The volcanic emission extends over about $10 \%$ of the whole surface area of Syria (Fig. 3).Volcanism is related to the movement of the Arabian plate towards the Eurasian plate, at a velocity of $18 \pm 2 \mathrm{mma}^{-1}$, in a NNW direction (McClusky et al2000). Eruptions, flooding cover significant areas, where the Cenozoic basaltic lavas may be up to $500 \mathrm{M}$ thick and are covered by Tertiary and Quaternary sediments (Al Mishwat and Nasir 2004). 


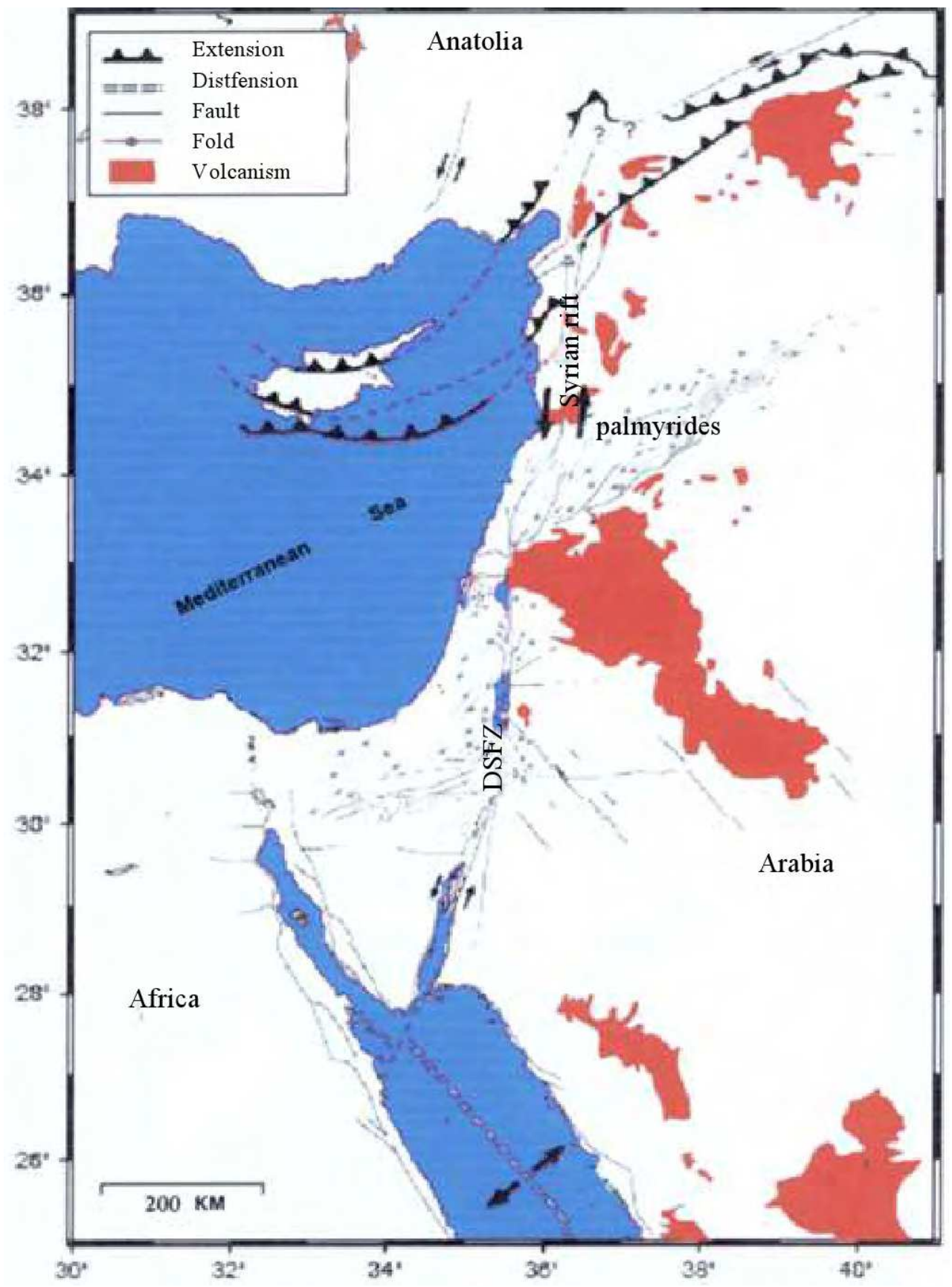

Fig. 2. The Arabian interplatplate volcanism occurrence in its tectonics context. (Adiyaman and Chorowicz, 2002 ). 


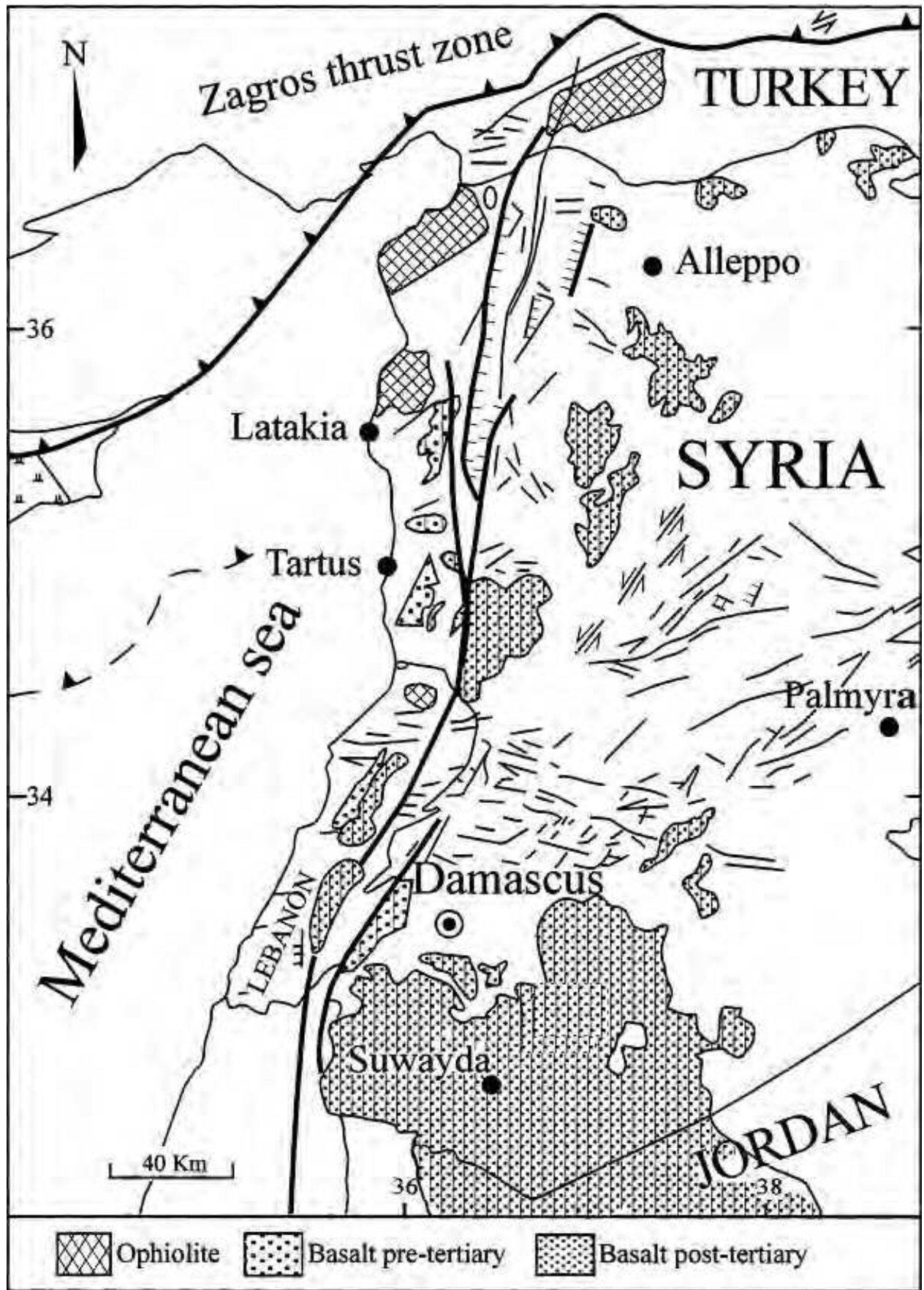

Fig. 3. The volcano-tectonics map of Syria. 
The volcanism is divided into two periods: upper Jurassic-lower Cretaceous, a period corresponding to a phase of extension of the Arabian plate margin, it corresponds to the Bhannes-Tayasir area of Syria sequence, constitutes isolated lavas or covered by the Neogene eruption, especially in the south of the country (west of Damascus), and in the center (Nabi Mata region) (Dubertret 1962,Ponikarov 1967,Laws and Wilson 1997).More recent Neogene-Quaternary eruptions are related to the formation of the Red Sea (24-16Ma), and Dead Sea rifts (8-0,4 Ma) (Ponikarov 1967, Bohanon et al.1989,Camp et Roobol 1989,Baker et al 1997,Chorowicz et al 2005). A number of eruptions have been identified from $17 \mathrm{Ma}$ to present. The last volcanic eruption took place in the South of the country, about 10000 years ago, as the end of the last eruption (<1Ma) (Dubertret 1933, Baker et al 1997).

Erupted lavas are in general very basic.rock compositions , cover the basalt-, picrobasalt-, and basanites fields on the diagram of Le Bas et al.(1986), (Fig.4),corresponding to a low differentiated magma(Ismail et al.2008). Major and trace elements data show overall similarities between recent and ancient ones, with however a more distinct alkaline trend and stronger variations of LILE-elements for recent lavas. These data involve small volume melt fractions.

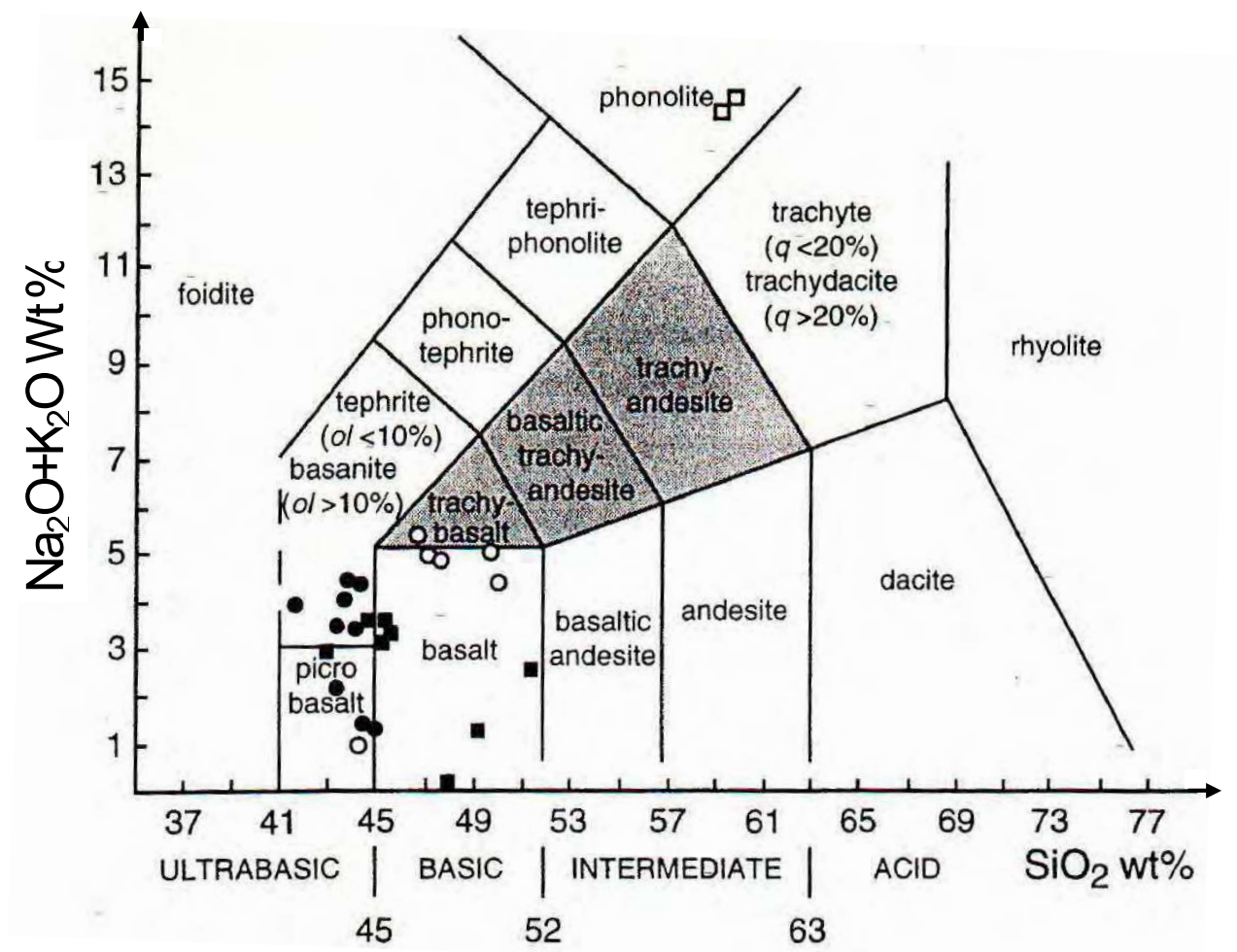

Fig. 4. Total alkalis-silica diagram of Le Bas et al (1986) for the basaltic rocks along the Syrian rift (Bilal and Touret 2001). 


\subsection{Composition of the lithospheric mantle}

A number of volcanoes along the rift contain a number of ultrasiques xenoliths, notably lherzolites, harzburgites and pyroxenites(Bilal and Touret 2001).Major rock -forming minerals are Olivine (Ol), Ortho- and Clinopyroxene (Opx and Cpx), with as common accessories spinel and amphibole. Microstructure varies from coarse-grained, coarsegrained-tabular to rare porphyroclastic (Ismail et al.2008).Most mantle peridotites are very well preserved with however a small variable possibility of local melting by the enclosing basalt around intergrain boundaries (Fig.5, A, B, C).

Most abundant rock types are harzburgites $(\mathrm{Ol}+\mathrm{Opx})$, which from their mineral composition and geochemistry can be divided into three groups (Ismail et al 2008): Group I, issued from a residual, depleted mantle, Groups II and III which correspond to a refertilized mantle, caused by the percolation of undifferentiated basaltic melt or ephemeral carbonate magmas through the residual lithosphere. Both groups correspond to a different degree of melting of the mantle peridotite (large for Group II, small for Group III).They are characterized by undispread mantle metasomatism with a carbonatite signature (Frezzotti et al 2002, Gregoir et al 2000), as notably indicated by the composition of clinopyroxene in some pyroxenites (Bilal and Sheleh 2004).

Rare garnet-bearing varieties have also been observed in the middle and south domains (Mheilbeh,Tel Thenoun) including few grenatites. These correspond most probably to lower crustal granulites, even if the occurrence of some high-pressure basaltic derivates cannot be excluded (Bilal and Touret 2001). The possible occurrence of xenoliths corresponding to lower crustal granulites is further indicated by the occurrence of sapphirine in some garnet and/or spinel-bearing websterites (Opx and Cpx-bearing pyroxenites, Fig. 5 D ,E) (Bilal $2009 \mathrm{~b}$, Bilal et al.2011). These basalts result from a complex polybaric melting process, first starting in the garnet peridotite stability field, then proceeding within the field of spinel peridotite( Bilal and Touret 2001,Bilal et al.2011).

\subsection{Fluid inclusions}

A great of pure CO2-bearing fluid inclusions have been found in olivine and pyroxenes from xenoliths, and in phenocrysts from enclosing basalts (Bilal and Touret 2001).This type of inclusions occur in virtually all mantle xenoliths in basalts worldwide(Roedder 1984),but in the present case some features confirm the occurrence of mantle metasomatism seen above in group II and III.The CO2 density in inclusions is very variable , most commonly around or lower the critical point(about $0,4 \mathrm{~g} / \mathrm{Cm} 3$ ). Fluid pressure at trapping conditions ,for a reference temperature of about 1000C,correspond to a depth of about $5 \mathrm{Km}$, namely the last magma chamber prior to eruption .But some primary inclusions contain fluid of much higher density recording deeper episode of the rock evolution. Highest fluid densities (up to $1,15 \mathrm{~g} / \mathrm{cm}^{2}$ ) are found in pyroxenites, notably in clinopyroxene. Fig 5 (F , G, H, I) show primary inclusions, of tubular shape, aligned along orthopyroxene or plagioclase exsolution lamellae within the clinopyroxene host .It is belived that these fluids are formed by a reaction illustrating the mantle metasomatism carbonatite connection:

Olivin+Carbonate (from the Carbonatite) $\rightarrow$ Clinopyroxene (with plagioclase and orthopyroxene in solid solution)+Co2.

P-T conditions of mineral equilibration in the xenoliths can are deduced from the pyroxene mineral assemblage (pyroxene thermometry) for the temperature (Wells 1977, Bertrand and Mercier 1986,Brey and Kohler 1990, Kohler and Brey 1990), and from the maximum fluid 

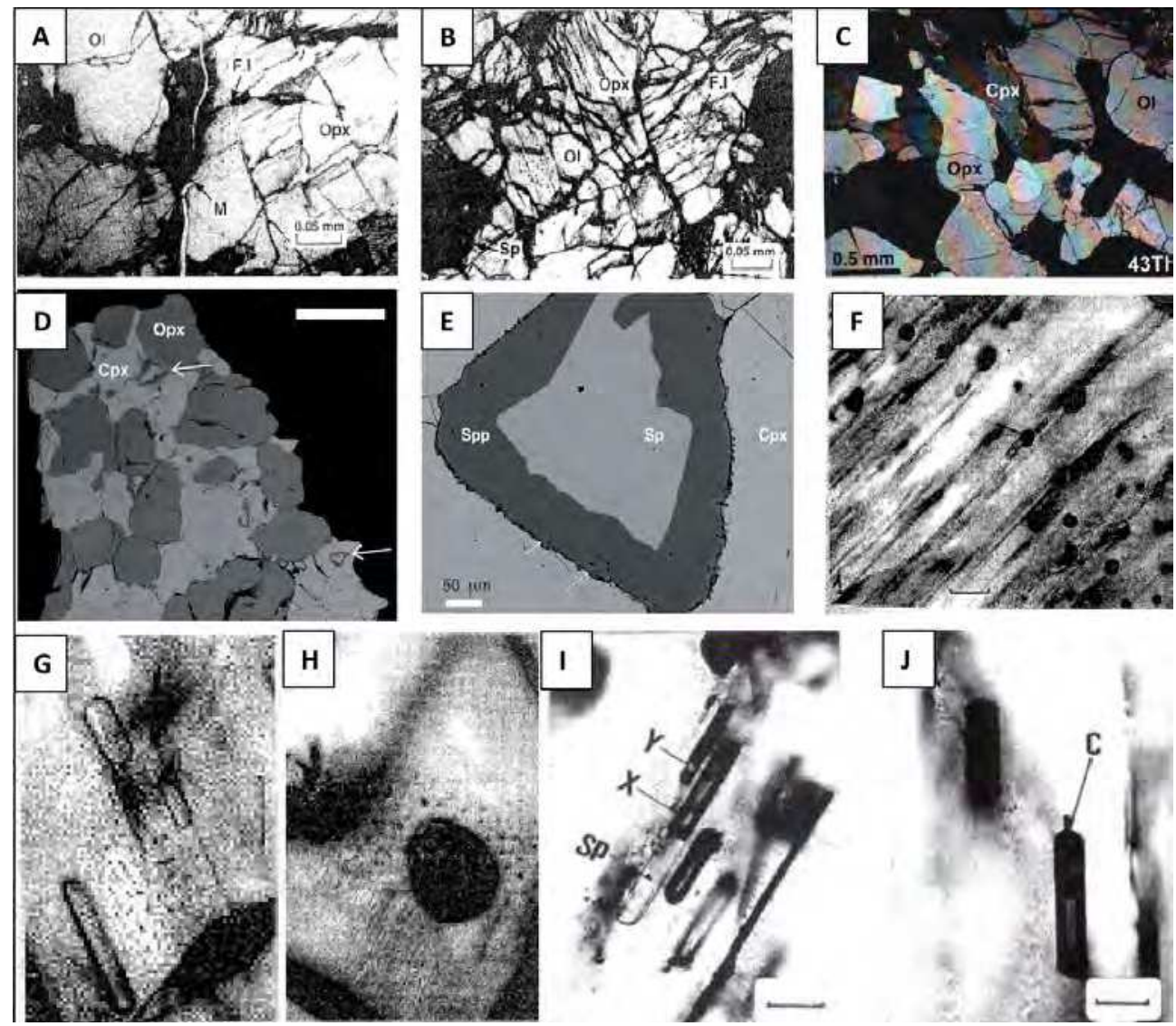

Fig. 5. Photomicrographs of petrographic features of mantle xenoliths, and fluid carbonic inclusions.

A: Coarse-grained microstructure harzburgit (sample37Th ,Tel Thenoun)-large Olivine (Ol) and Clinopyroxene(OPX) crystals shown a dark melt zone(M) at the intergranular boundary containing white veinlet filled with secondary minerals(opal, carbonate), and trail of secondary ,low density ,carbonic inclusions(FI), issued from $\mathrm{M}$, and disposed along the OPX cleavage plan. B: Coarse-grainedtubular microstructure spinel lherzolite (sample 34Th,Tel Thenoun)-large pyroxenite crystals, subordinate olivine $(\mathrm{Ol})$, and large spinel crystals surrounded by a dark reaction zone.Primary $\mathrm{CO} 2$ inclusions(FI) are disposed in the core of some clinopyroxene crystals. C:Coarse-grained microstructure in harzburgite (sample 43Th,Tel Thenoun).D:composite BSE image section(sample Th12,Tel Thenoun).The submillimitric coronitic feature correspond to spinel (light grey core) rimmed by sapphirine(dark grey).Scale bar $2 \mathrm{~mm}$.E: More clear of coronitic spinel of figure $\mathrm{D}$, where the sapphirine corona(dark grey) is continuous.A thin rim of symplectite is hardly visible between sapphirine and clinopyroxene.F:Carbonic (pure CO2) fluid inclusions(black circles) in exsolution features in the butterfly-wing structure, in pyroxenite(sample 135Th,Tel Thenoun).Scale bar50 micron m. G:Tubular carbonic inclusions in pyroxene (sample135Th,Tel Thenoun),Scale 20 micron m.H:Details of the butterfly-wing structure around inclusion in olivine(sample 11Th,Tel Thenoun).Scale20 micronm. I, J: Carbonic inclusions in clinopyroxene. $\mathrm{X}$ and $\mathrm{Y}$ supercritical CO2 (homogenization temperature $=15$ C),(sample 135Th,Tel Thenoun).bar 20 micronm. 
density in primary carbonic inclusions, for the pressure (Bilal et Touret 2001,Bilal et Sheleh 2004).Using theses parameters the figure (6),show the obtained Results, which correspond to about $1100-1300 \mathrm{C}$ for the temperature, $10-13 \mathrm{~Kb}$ for the pressure.

In conclusion it is suggested that the volcanic activity along the Syrian rift is due to the presence under the Arabic plate of a mantle plume(Stein and Katz 1989,Stein and Hofman 1992 ,Stein et al 1993), active since Cretaceous times, locally refertilizing a residual (oceanictype) lithospheric mantle (Bilal and Touret 2001,Bilal and Sheleh 2004).

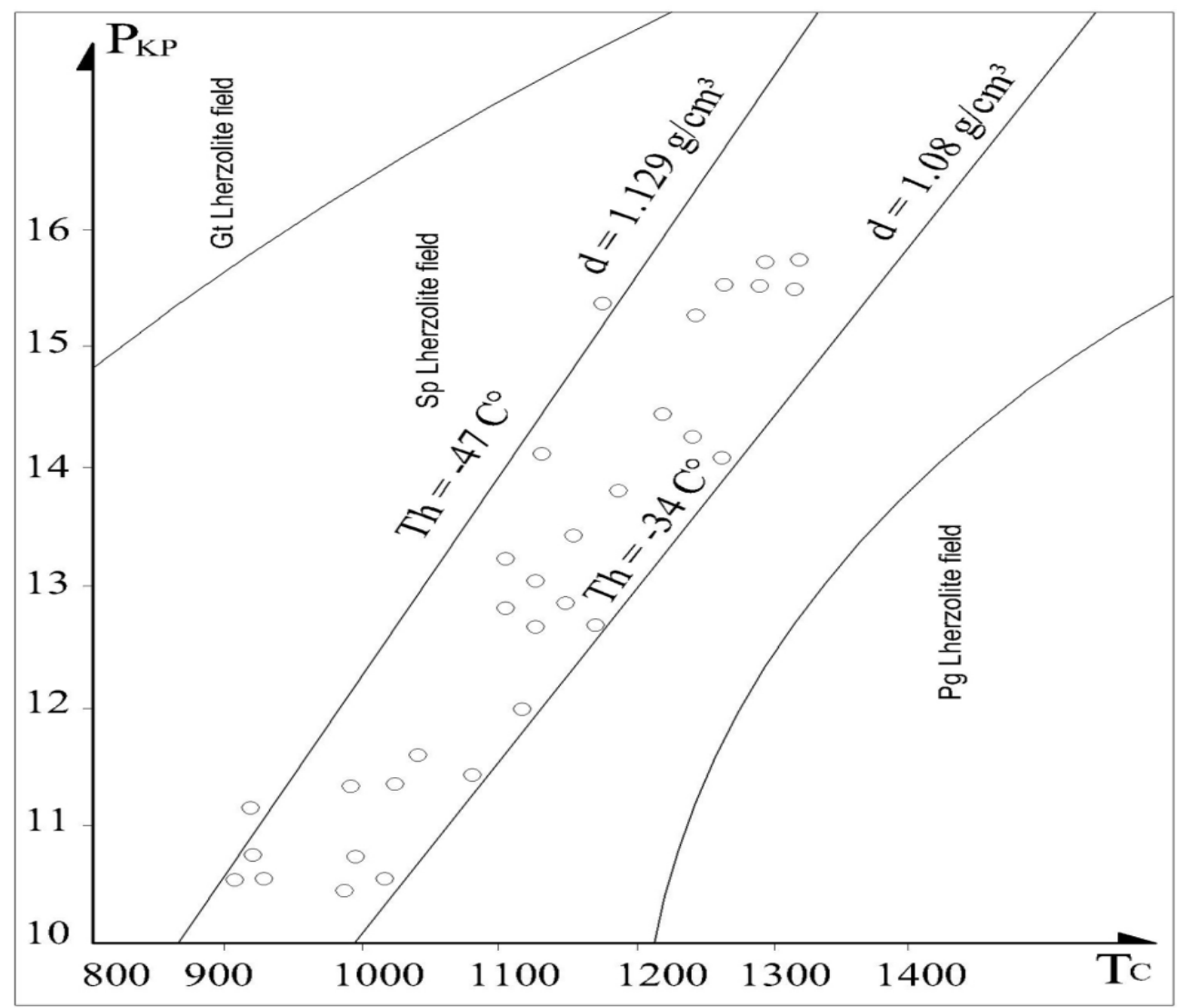

Fig. 6. Tthermparometric conditions (P, T), of Syrian mantle xenoliths (Bilal and Touret 2001, Bilal and Sheleh 2004).Th: homogenization temperature of CO2 fluid inclusions; d: density of $\mathrm{CO} 2$ liquid.

\section{Tectono-seismicity characteristics}

The tectono- seismicity characteristics are deducted from the satellite imagery, the field survey, the seismic observatories data, the odometric measurements, and the analyzing of ancient and recent earthquakes. 


\subsection{Tectonics}

The Syria platform is constituted from several structural units, which have been formed at different periods since the Permo-Trias. The map of figure (7), shows these principles units: The Palmyrides in the center; the graben of Euphrates and the Djebel Abdelaziz in the East; the Afrin region and the Aleppo plateau in the North-West; and the Coastal chain at the west of the Levant fault ( Al Abdalla 2008).

The West of Syria is occupied by an important structure, locally named the Syrian rift, and worldly known the Levant fault, corresponding to the northern part of the Dead Sea fault zone (DSFZ), which forms the boundary between the African and Arabian plates. The tectonic activity along its northern part, the Yammouneh fault and northward continuation is still a subject of controversy. Between those who maintained that this segment is poorly active(Girdler 1990,Butler et al1997,1998,Butler and Spencer 1999), and others who concluded ,from the earthquakes study, that this segment would then be active until it

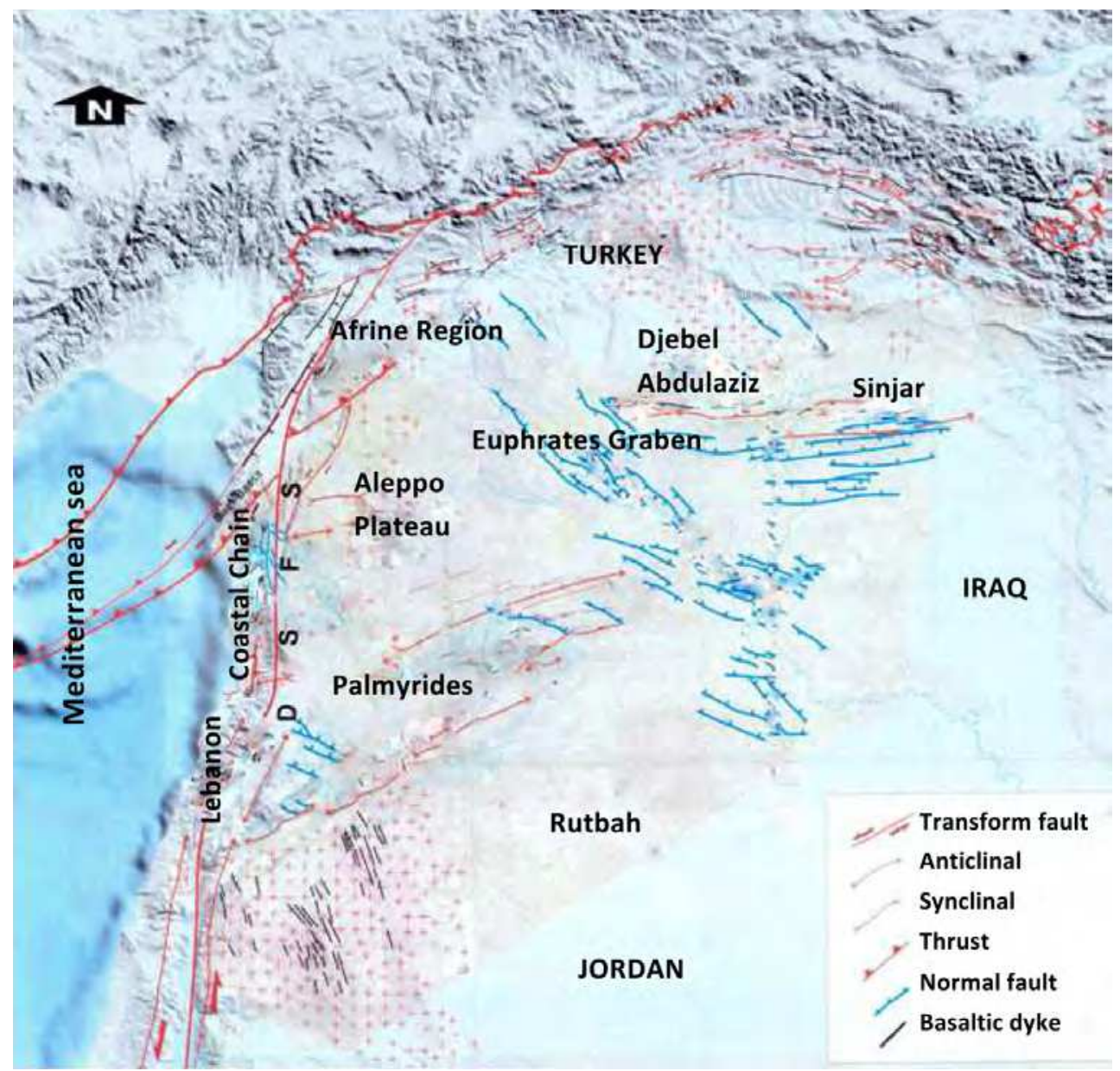

Fig. 7. Principles structural units of Syria, northwest of the Arabian plate (Al Abdalla 2008) 
reaches the Africa-Arabia-Eurasia triple junction near Maras(Khair et al 2000,Meghraoui et al.2003), confirmed by recent field studies (Chorowicz et al.2005,Bilal 2009a,b).

Thus, the Syrian rift is an active seismic zone oriented North-South.It could be identified either by a satellite image or in the field (Fig.8). It cross the middle east through more $1200 \mathrm{Km}$., from the Aqaba gulf in the South, to the Turkey in the North (Bilal and Touret 2001), successively through Lebanon, Syria and Turkey.

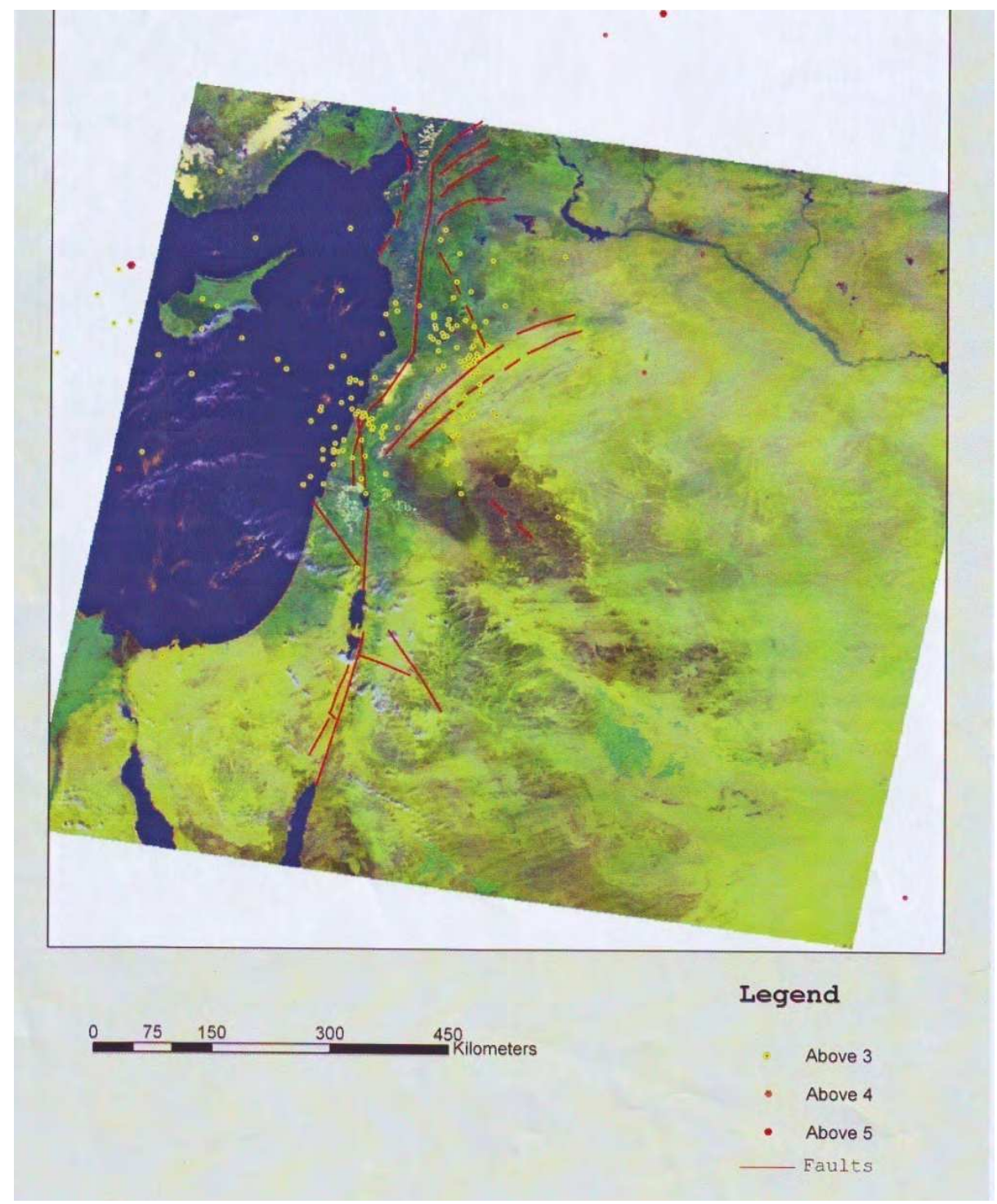

Fig. 8. Structure of the Syrian rift from the satellite image, Landsat 2005, and epicenters of the seisms in 2005 - 2006 after the Syrian seismic centre 
In Syria, the Levant fault continues towards the North, between Damascus and Tartous, by the Yammouneh fault. This last structure marks an important transition to the Palmyra chain, making a sort of hinge between the northern and southern parts of the rift. The rift continues to the north through the El Ghab basin, and it disappears in the Taurus zone, in Turkey, in the Maras's triple junction point which relays Africa-Arabia-Eurasia. Many arguments, from structural analysis and field observation, in addition to satellite imagery data, and geomorphologic analysis, point to a recent, up to present day tectonic activity along this structure, e.g. mylonites and fine-grained shear zones, filling of pull-apart basins, deformed small active ravines and formation of scarps.

The Syrian rift corresponds to a transform fault, with lateral displacements decreasing from more than $100 \mathrm{Km}$, to the South, to less than $30 \mathrm{Km}$, to the North, at the level of the Yammouneh fault (Walley 1988).The secondary faults and fractures deduced by the satellite images (Bilal1994 a,b) ,and detected in the field (Lovelock 1984,Sawaf et al. 1993),support this results, but more studies are needed to more explore others factors.

Many faults, as shown by the structural analysis and field observation, in addition to satellite imagery data and geomorphologic analysis, attest that have recently been or are still active along the Syrian rift. This is notably indicated by several phenomena: 1) the local transformation of basaltic rocks into mylonites and fine-grained shear zones. Carbonate basement rocks may also be deformed; they are more mylonitic because more easily fragmented than basalts. 2) The occurrence of pull-apart basins filled with quaternary sediments. 3) The deformation of small active ravines, with the formation of scarps (Chorowicz et al.2005, Bilal 2009a, b).

\subsection{Seismology}

Syria, the northern part of the Dead Sea Fault Zone (DSFZ), has a long record of active seismicity (Taher 1979, Al Tarazi 1999). Field observations, physical effects on ancient building structures and movement analysis show that tectonic is still active at present time (Khair et al.2000, Meghraoui et al2003, Chorowicz et al 2005).

Most major seisms in Syria occur in two regions: Either within or close to the rift zone, along a North - South direction, or SW - NE oriented, along the Damascus Palmyra mountain chain. This last domain does not contain any volcanic activity. Earthquakes in this region can only be caused by superficial deformation of the sedimentary cover.

Many of seisms take place within the litohsphere, in response to active fault displacement (Lay and Wallace1995,Yeats et al.1997), but others could also originate when the crust is subducted into the mantle, or along rifts in response to an ascending hot spot (plume) (Yeats et al.1997,Bilal and Sheleh 2004).This is precisely what may happen in Syria. The study of volcanic xenoliths has identified a hot spot under the Arabic plate (Stein and Hofman 1992, Sharkov et al.1993), starting during Cretaceous and ascending continuously until present time (Bilal and Touret 2002, Bilal and Sheleh 2004). This part aims to analyzing the seismicity distribution in the Syrian territory, using tectonic activity, laboratory measurements, and historic and recent earthquakes records. It will also attempt to compare these data with volcanic parameters.

\subsubsection{Seismic parameters}

The movement rate-displacement along a given fault could be estimated in the region of Homs, where important basaltic eruptions took place 6 Ma ago (Sharkov et al.1994, Butler et 
al.1998). The overall displacement along the fault since the time of eruption, in other words the total length of pull-apart, could be estimated from the displacement of the famous "Krak des Chevaliers" in respect to the main Shine volcano (Fig.9). This gives $16 \mathrm{~km}$, significantly less than other estimates $(20 \mathrm{Km}$, Chorowicz et al 2005). This would give an average displacement rate of 2,7 -3,3 mm/year, in line with estimates along the Wadi Araba fault, in the northern part of the Levant fault $(4,6+/-2 \mathrm{~mm} /$ year, with a decreasing value of 2,3 $\mathrm{mm} /$ year for the last $12 \mathrm{ka}$, Le Beon 2008). In Syria, the displacement rate in the region of Homs corresponds to a maximum value. The movement rate, estimated by different methods, decreases significantly in the others regions. It is: $1-1.5 \mathrm{~mm} / \mathrm{yr}$ in the region of Palmyra, less than $1 \mathrm{~mm} / \mathrm{yr}$ in the Eastern and North Eastern parts of the country (Bilal 2009 b, Tab.1).

\section{Region}

El Ghab, the Syria rift

Palmyra chain

Eastern Syria, Russafeh

Afrin region

Northern east Syria
Movement rate $/ \mathrm{mm}$. Yr.

2, 7-3, 3

1,5

$1-1,5$

1

$<1$
Method

Basaltic displacement

Monuments cracks

Monuments cracks

Field measurements

Field measurement

Table 1. Movement rate in different regions estimated by different methods

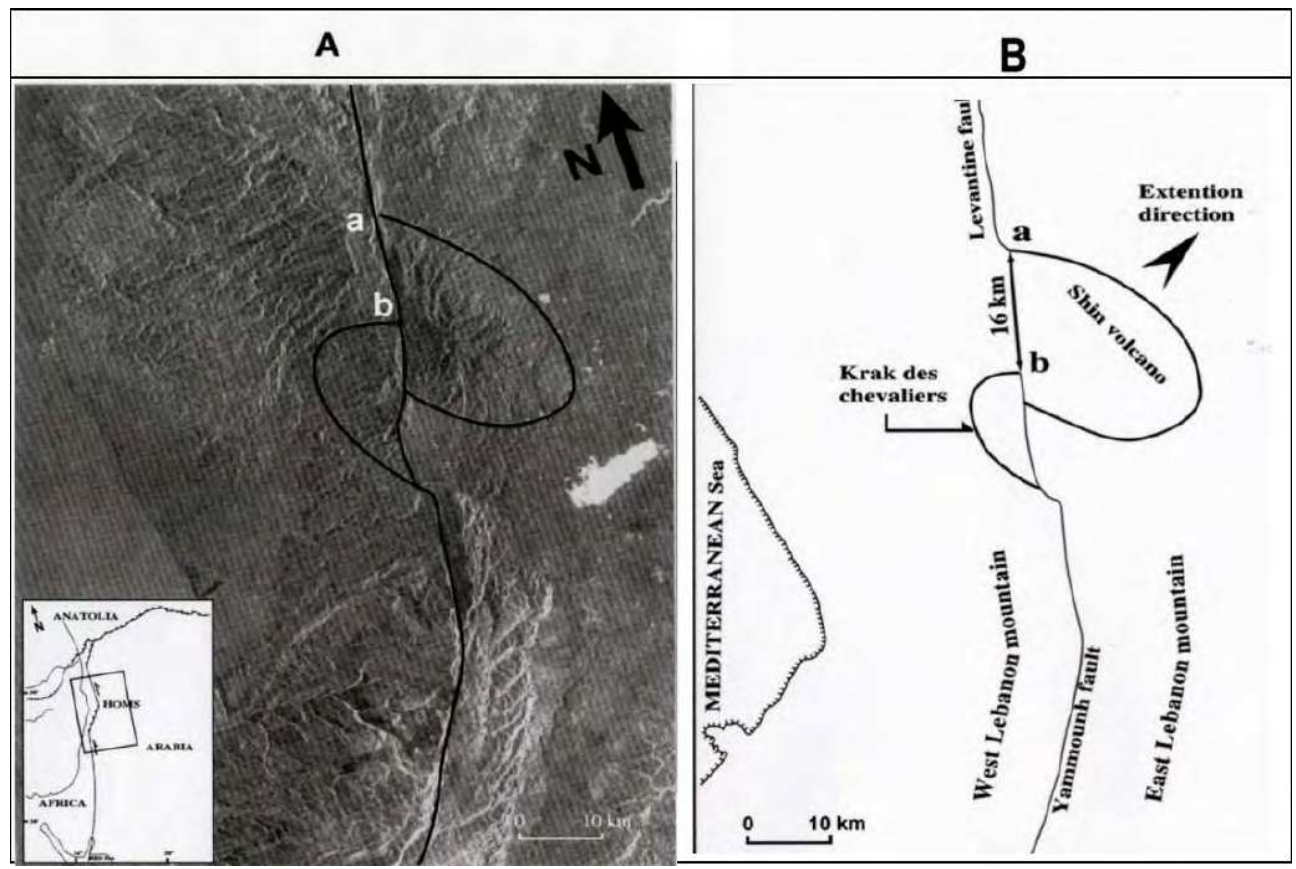

Fig. 9. Movement rate estimate, from field observation and satellite imagery analysis (Landsat TM 1995). ab: displacement, estimated at 16Km during $6 \mathrm{My}$, the age of the Homs basalt. 
These results are confirmed by physical effects on the building structures in the region (field measurement on houses, measurement by Bilal and Ammar 2004, unpublished data). They can be taken as an average value for the movement rate repartition in the whole territory.

For an earthquake of a given intensity, defined by the value of the Magnitude (in Richter), the action on a builded structure, which result in the greatest number of casualties, depends from two sets of parameters: the characteristics of the structure itself and the nature of the ground on which it is built. Several equations are proposed to relate all these variables (Bojoroque and DeRoeck 2007, Ozkan 1998). The Syrian code (2004), used in this work is based on the following equations:

$$
\begin{gathered}
\mathrm{Z}=\mathrm{V} / \mathrm{IKCSW} \\
\mathrm{C}=1 / \mathrm{T} \\
\mathrm{T} \sim 0,1 \mathrm{~N}
\end{gathered}
$$

Where $\mathrm{V}$ is the horizontal shear force, I correspond to the type and geometry of the structure (bridges, tunnels, towers, dams, etc.), $\mathrm{K}$ the inelasticity coefficient of the structure, $\mathrm{C}$ the dynamic coefficient, linked to the nodes propagation period (T), and the number of stages (N), S a coefficient relative to the soil, and finally, $\mathrm{W}$ the total weight.

This seismic acceleration coefficient $(Z)$ is a critical parameter. Estimated in $\mathrm{cm} / \mathrm{s} 2$, it describes the reaction of an object -structure in a limited zone -to an earthquake of a given intensity. Its value changes from region to other after the upon seismic parameters, and so in the same region according to the estimated parameters values, from 0 to a variable value, reaching 1, $5 \mathrm{~cm} / \mathrm{s} 2$ (Bojoroque and DeRoeck 2007).

For the dams $\mathrm{Z}$ is estimated, in Japan, at 0,1- 0, 12 for weak earthquake zones, and 0, 15 for strong zones. It is taken between 0, 05 and 0, 20 in Turkey, and between 0, 03 and 0, 24 in India (Bilal 2009). A coefficient of 0, 1 indicates that a building is designed so that 0,1 of its weight can be applied horizontally during an earthquake

In Syria $\mathrm{Z}$ ranges between 0 and 0,25, depending on the region.It is 0,25 in $\mathrm{Al}$ Ghab region, 0,12 in Palmyra, and 0,05 - 0,1 in Deir Zour, in the East.

\subsubsection{Seismicity-time analysis}

The repetition of an earthquake (frequency return period of an earthquake in the same locality), namely the seismic cycle is controversial (King 2004, Maderiaga 2004). However if an earthquake is unique for a given locality, the distruction of earthquake activity with time is of major importance.

Therefore, the historical record of ancient earthquakes has been investigated. Only were used these verified by different sources (Taher 1979, Al Tarazi 1999). Available historical data covers a wide period with variable magnitude: Ancient time between 750 and 1800, with magnitude estimated at 7.5-6.5 (Meghraoui 2003), it becomes 6 - 5 between 1800 2000 (UNISCO 1983,Stiro1992,Sbeinati and Darawcheh 1992,Al Tarazi1999),less than 5 for the period of 1960 to 2000 and between 4,9-4 at present (USGS 1999). The results are represented by the histogram of figure (10). They show that the seismic intensity tends to decreases with time, in agreement with recent estimates on the movement rate (Le Beon 2008). 


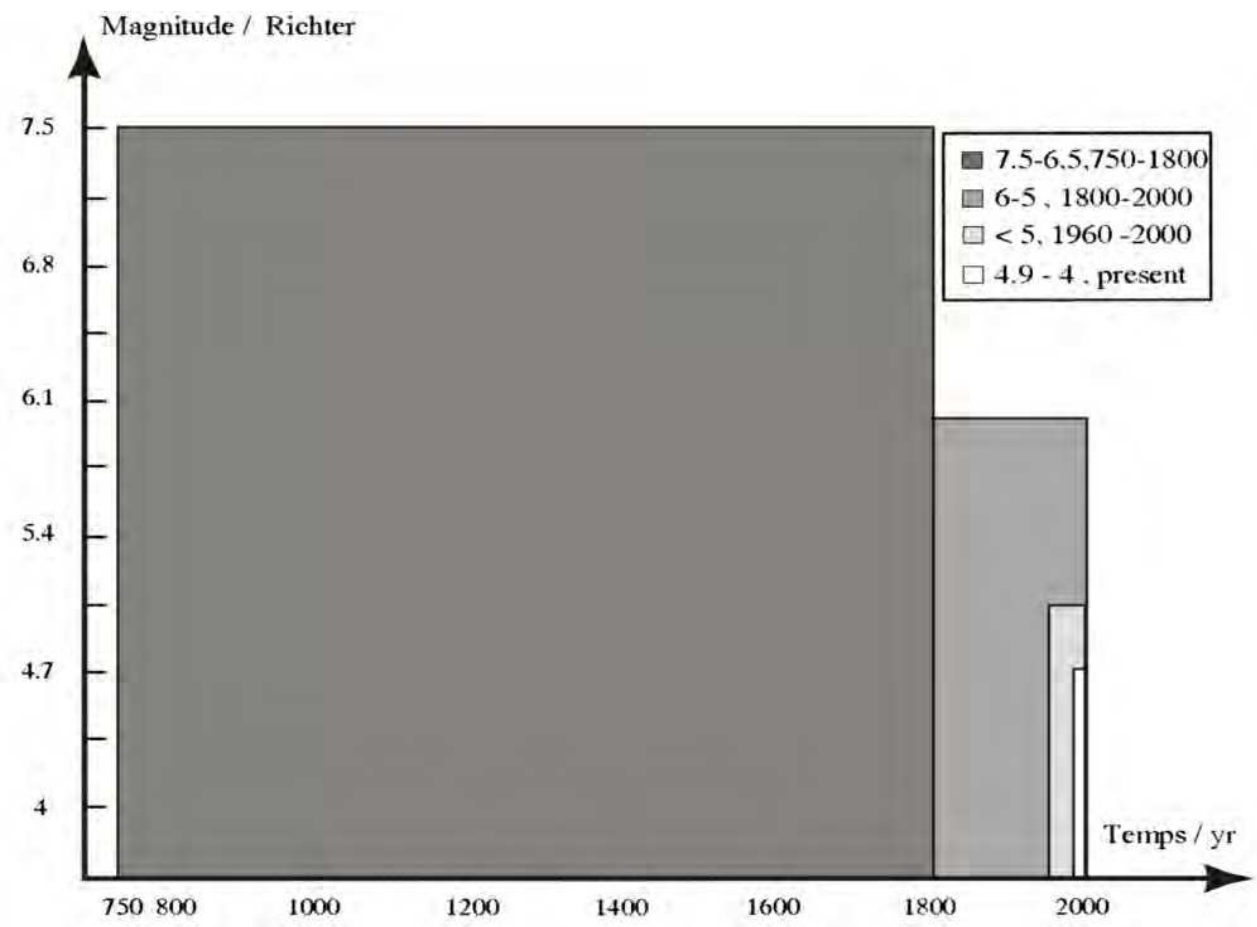

Fig. 10. Histogram of the seismicity evolution in time, after their magnitude and age.

For recent seisms, we have collected good data, especially from the physical effects on the structures and the station seismic net (Fig.11). They are distributed in the whole of the country and in the off shore.

\subsubsection{Seismic hazard zoning map of Syria and Arab plate}

In order to evaluate the seismic hazards on the whole territory of Syria, and to examine their effect on building structures, odometric experiments on the more representative soil types occur in the country, have been performed in laboratory. Using scale of magnitude intensity of $7,7.5,8$, and 8.5 respectively, the elasticity modulus $(E=$ power/surface $=$ Kilo Newton / $\left.\mathrm{m}^{2}\right)$, and the Poisson ratio $(\mathrm{P}=$ executed displacement $/$ original displacement $=$ deformation $\%)$, have been determined. They allow the determination of the soil rigidity and the behavior of building during a seism (interaction soil-seism for a given building). The experiments have been measured on more than 80 litho- logical samples. Measurements were analyzed using the SAP Software (computer and structures Inc. USA, Bilal and Mahmoud 1997). Results are given in terms of relative unity response to seismic hazard, namely relative damage, the result of seism-soil effect on building, estimated from low to strong. It is maximal along the rift (moderate), and decreases gradually towards the East, East South and East North (low) in line with the rate movement, and seismic acceleration coefficient evolution (Fig.12B). 


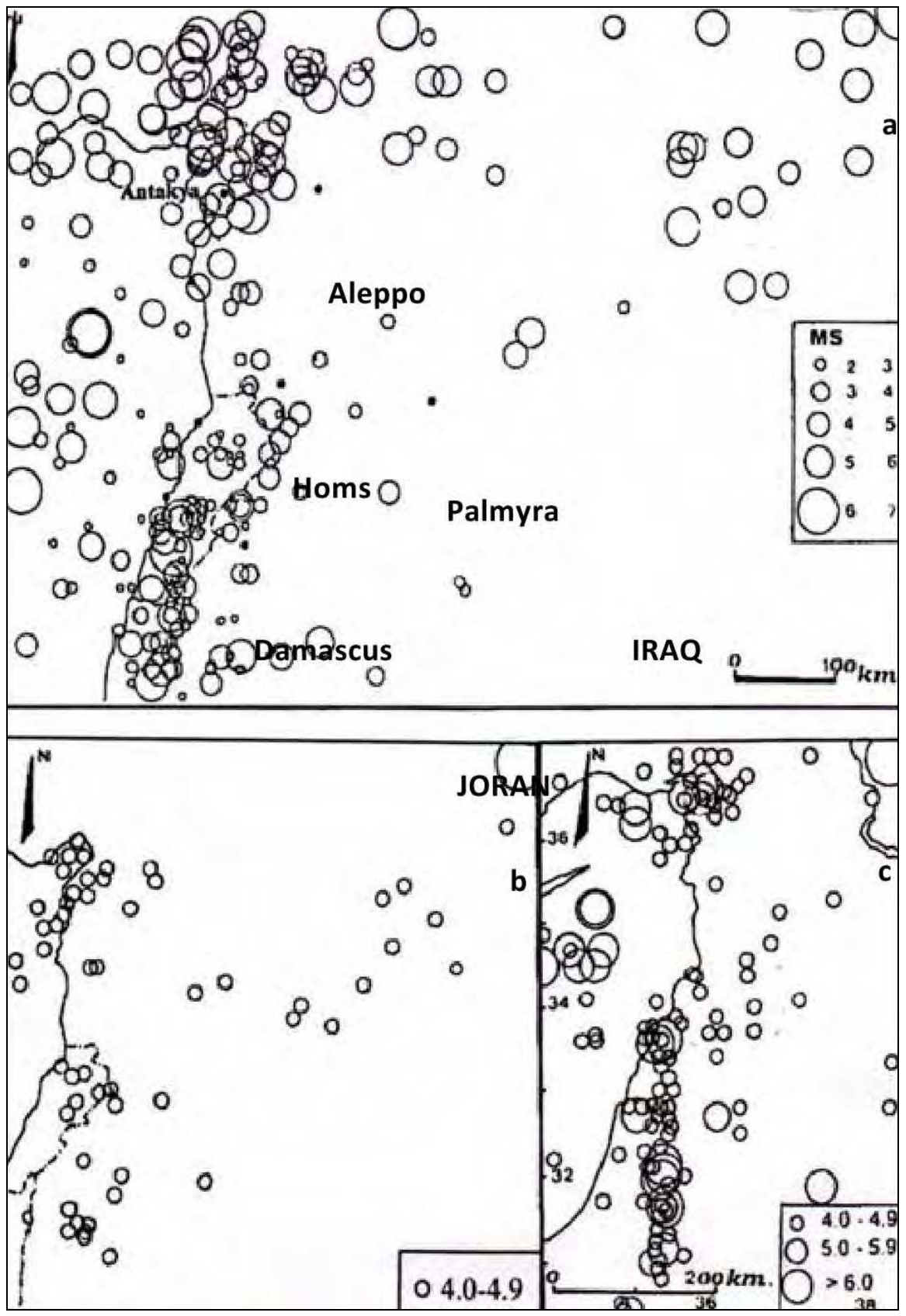

Fig. 11. Occurrence of the recent seismicity in Syria: a-Sbeinati and Darawcheh for the XX century (1992),b-USGS for the period of 1961-1983,(in Stiro 1992);c-USGS for the last years(Monitor,vol.5,1,1995). 


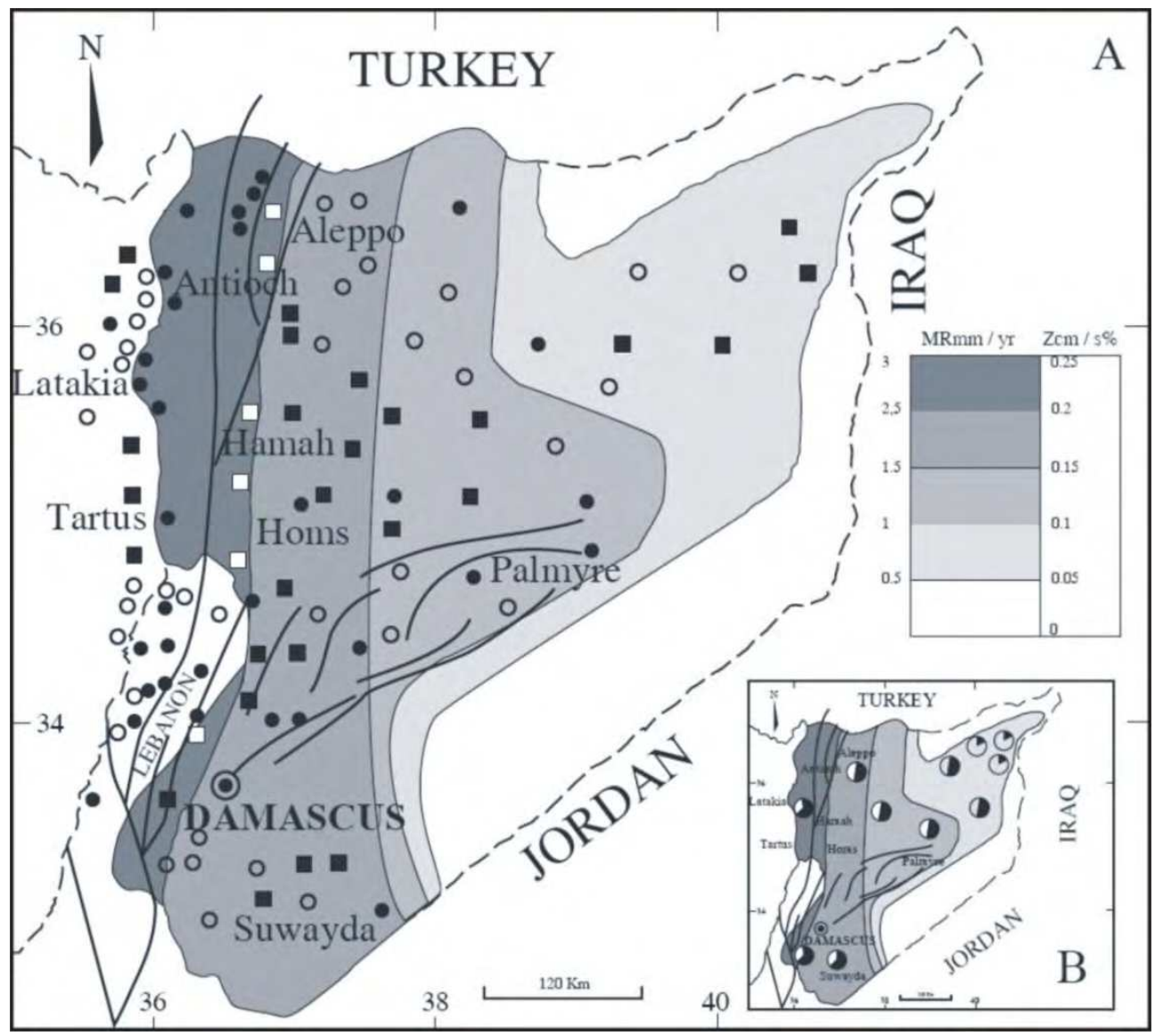

Fig. 12. Seismic map of Syria, showing the five seismic zones, and distribution of the earthquakes which their magnitude more than 4; white square: $M>6$; black circle: $5<M<6$; black square: $M<5$; white; circle: $M=4,9-4(A)$, and odometric result where the black part indicate the relative damage(B).

According to the movement rate, estimated in the field between $<1 \mathrm{~mm} / \mathrm{yr}$ and $2,7-3,3$ $\mathrm{mm} / \mathrm{yr}$, the $\mathrm{Z}$ value estimated at $0-0.25 \mathrm{~cm} / \mathrm{S} 2$, the relative seismic intensity measured in laboratory (Bilal and Mahmoud 1997), the analysis of recent seismicity documented by the seismic network, and finally historical record, we have identified a number of seismic zones and corresponding seismic intensity (Tab.2).

These zones are represented on a seismic map of Syria (Fig.12A), established here for the first time. This map divides Syria into five zones, each of which corresponds to a given seismic intensity value. Zone one has the highest seismic intensity risk, with most potential damage for the constructions, while zone five has the lowest one.

On the same figure $(12 \mathrm{~A})$, the earthquake epicenters with a magnitude higher than 4 are projected. They occur in the whole territory but mostly in zones 1 and 2, associated with volcanism, or along the Damascus-Palmyra mountain chain. Only some earthquakes had a 


$\begin{array}{cccc}\text { MR mm/yr. } & \mathrm{Zcm} / \mathrm{S} 2 & \text { Seismic zone } & \text { Seismic intensity } \\ 0 & 0 & 0 & \text { none } \\ <1 & 0.05 & 0-1 & \text { very low } \\ 1 & 01 & 1 & -2 \mathrm{~A} \\ 1.5 & 0.15 & 2 \mathrm{~A} & \text { middle-low } \\ 2 & 0.2 & 2 \mathrm{~B} & \text { middle } \\ 2.5 & 0.25 & 2 \mathrm{C} & \text { moderate }\end{array}$

Table 2. Calculated seismic parameters, corresponding seismic zones and their intensity.

magnitude higher than 7, 5- 6, 5, even if this remains controversial. Most recorded earthquakes in the twentieth century have a magnitude less than 6. Out of hundred earthquakes in the region and off shore, $25 \%$ have a magnitude between $6-5$, and most of them have a magnitude less than 5. All together, the whole Syria shows moderate seismicity, compared to the north, Taurus-Zagros fault zone, or to the south, under the Indian Ocean expansion.

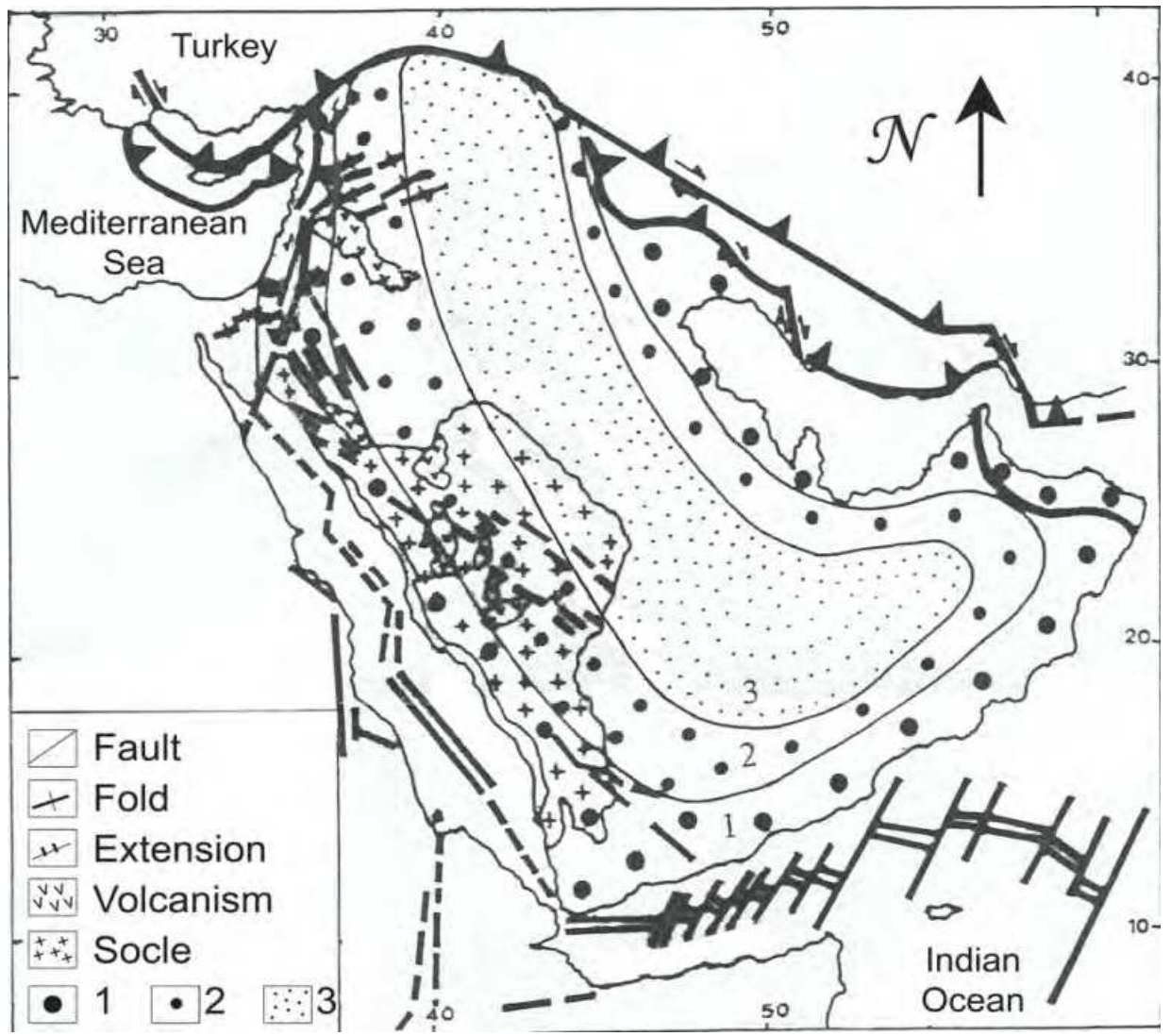

Fig. 13. An extrapolated seismic zoning map of the Arab plate. Zone 1, the highest seismic intensity zon;zone 2,the intermediary one and zone 3 , the lowest one. 
Using data obtained by deferments sources ( UNESCO 1983,Barrier et al 2004,Al Damegh et al 2005,Le Beon 2008,Bilal 2009b), and the seismo-tectonic parameters, an extrapolated seismic zoning map for the Arab plate is established(Fig.13).It distinguishes between three seismic zones: zone 1 , the highest seismic zone intensity with major damage risk; zone 3 ,zone of low seismic intensity with lowest potential risk , and zone 3, the intermediary zone with intermediary potential risk. These results need to more verification by a qualified team.

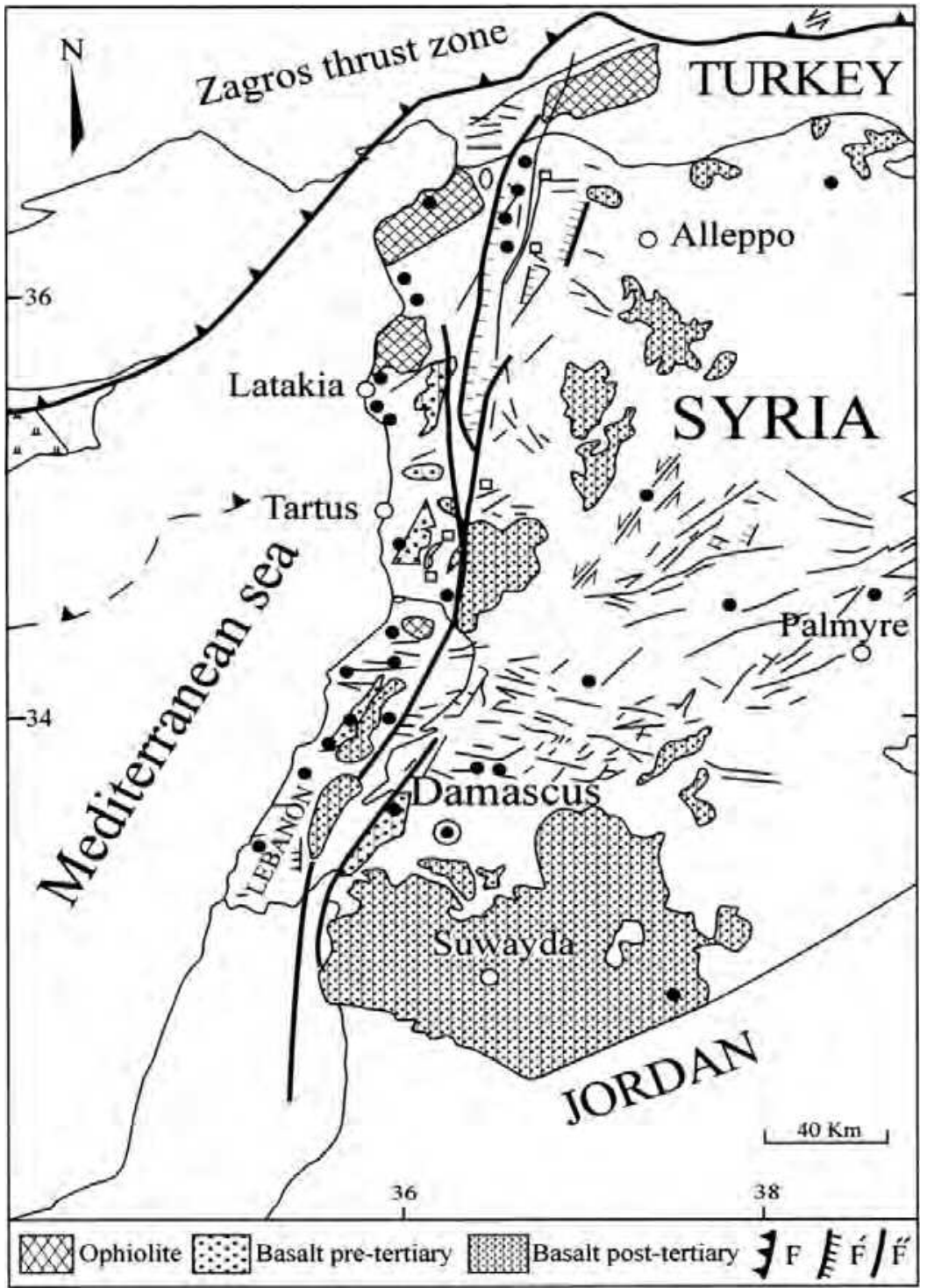

Fig. 14. Regional tectonic map of Syria showing the rift structure, volcanism and the distribution of earthquakes epicenters (in black circles), with the highest magnitude $(>5-7,5)$. 


\section{Conclusion}

The Syrian rift is a world structure, and constitute the north part of the Dead Sea Fault Zone (DSFZ).Structural analysis using variable techniques attest that many faults have recently or are still active to occuresent along the Syrian rift. This is notably indicated by two phenomena: volcanism and seismicity.

The composition of the underlying lithospheric mantle points to a complex history involving polybaric partial melting at various degrees, starting in the garnet - and proceeding in the spinel stability field. Some clinopyroxenes at least record mantle metasomatism, caused by ephemeral carbonate magmas or percolating basalting melts issued from a mantle plume under the Arabic plate.

Most major seisms in Syria occur in two zones (Fig.14): with the rift zone, in a North - South direction, but not exactly along the fractures. Most epicenters occur westward along the coast or in the sea. The other zone is SW - NE oriented, along the Damascus Palmyra mountain chain. It does not seem to be related to any volcanic activity, but corresponds namely to superficial deformation of the sedimentary cover.

For volcanic-related seismicity, Petrological data from volcanic xenoliths have identified the existence of a hot spot (plume), under the Syrian rift. In the earliest period of volcanic activity (Cretaceous), this plume started at the level of mantel garnet peridotite, leading to a marked explosive volcanism. It may be hypothesized that this type of volcanism did correspond to major seismicity. In more recent time, the plume head tends to rise, while at the same time migrating towards the West. This was accompanied by a more effusive type of volcanism, associated to the moderate seismicity, presently shown. The last eruption (10.000 y) occurred in the large volcanic massif at the South (Djebel Al Arab). With one exception, no major seism relates to this last eruption. This recent massif, by far the larger in Syria, seems to distantiate from the rift zone, at the difference, notably, of older Cretaceous volcanism.

At the scale of the human observation, the seismicity does not seem to be directly related to present-day volcanic activity.Either reminiscence of ancient volcanism, or consequence of superficial deformation. Both phenomena tend to fade out with time, in line with the decrease of major seismic intensity which has occurred during the last millennium.

\section{References}

Adiyaman, O. and Chorowicz, J. (2002)-Late Cenozoic tectonics and volcanism in the northwestern corner of the Arabian plate:a consequence of the strik-slip Dead Sea Fault Zone and lateral escape of Anatolia.Journal of Volcanologyand Geothermal Research, 117, 327-345.

Al Abdalla, A. (2008)- Evolution tectonique de la plat-form Arabe en Syrie depuis le Mesozoique. These Doctorat, Universite Pierre et Marie Curie.302p.

Al Damegh, K; Sandvol, and Barazangi, M. (2005) - Crustal structure of the Arabian Plate: New constraints from the analysis of teleseismic receiver functions. Earth and Planeta Sciences Letters, 231, 9, p. 177-196. Contrib. Mineral.Petrol. 50: 79-92.

Al Mishwat, AT. and Nasir, SJ. (2004)- Composition of the lower crust of the Arabian plate: a xenolith perspective. Lithos, 72: 45-48.;

Al-Tarazi, E. (1999)- Regional seismic hazard study for the eastern Mediterranean (TransJordan, Levant and Antakia) and Sinai Region. J. of African Earth Sciences, vol. n³, 743-750. 
Agard, P; Monie, P; Gerber, W; Omrani, J; Molinaro, M; Meyer, B; Labrousse, L; Vrielynk, B; Jolivet, L; and Yamato, P. (2006)-Transient, synobduction exhumation of Zagros blueschists inferred from P-T, deformation, time, and kinematic constraints: Implications for newtethyan wedge dynamics.J. Geophysics. Res. 111, B11401, doi: 10.1029/2005JB004103.

Baker, MA; Menzies, MA; Thirlwall, MF; McPherson, CG. (1997)- Petrogenesis of Quaternary intraplate volcanism, Sana'a, Yemen; implications for plumelithosphere interaction and polybaric melt hybridization. Journal of Petrology, 38, 1359-1390.

Barrier, E;Chamot-Rooke,; and Giordano, G. (2004)- Carte géodynamique de la Méditerranée. Commission de la carte géologique du monde.

Bertrand, P. and Mercier J.C.C. (1986)-The mutual solubility of ortho and clinopyroxene : towards an absolute geothermometer for the natural system? Earth.. planet.. Sci. Lett. 76, 109-122.

Bilal, A. (1994a)-Remote sensing new tectonic data of the Arabian plate.IGARSS 94, California, USA, p58.

Bilal, A. (1994b)- Une nouvelle pensee sur l’origine du complexe ophiolitique, Syria.15e Renu. Ann. Sci. Terre. Nancy, p. 105. Livre en depot. Soc. Geol. France.

Bilal, A. (2009a) - Seismicity and volcanism in the rifted zone of western Syria. C. R. Geosciences, 341, 299-305.

Bilal, A. (2009b)- Tectono- Seismicity and petrological study of the Syrian rift. Tishreen University Journal for Research Scientific studies, Basic Sciences, Vol.31, no (1), pp 127-145.

Bilal, A; and, Sheleh F. (1988) - Pétrologie des enclaves ultrabasiques dans le basalte du sud de la Syrie. J Univ. Damas, 109: 49-81.

Bilal, A.and Sheleh, F. (2004)- Un "point chaud" sous le système du rift Syrien : données pétrologiques complémentaires sur les enclaves du volcanisme récent. Comptes Rendus Géosciences, 366, 197-204.

Bilal, A. and Mahmoud, M. (1997)-Soil-Structure interaction effect during earthquakes in Syria. Inter. Post-SMIRT conference on seismic isolation. Taormina- Italy, August 25-27th.

Bilal, A. and Touret, J.L. (2001)- Les enclaves du volcanisme récent du rift Syrien. Bull. Soc. Géol. Fr. Tom 17 2, nO1, 1-14.

Bilal, A. and Ammar, O. (2004)- Field measurements on houses and structures.Unpublished data, Syria.

Bilal, A; Jambon, A; Boudouma, O; Badia, D; and Sautter, V. (2011)- Mantel-derived sapphirine in the webstrite xenoliths ofTel Thenoun-Syria. (submitted).

Bohanon, RG; Naeser, CW; Schmidt, LD; and Zimmermann, R.A. (1989)- The timing of uplift, volcanism, and rifting peripheral to the Red Sea; a case for passive rifting ? Journal of Geophysical Research, B 94, 1683-1701

Bojoroque, J. and DeRoeck, G. (2007)- Determination of the critical seismic acceleration coefficient in slope stability analysis using finite element methods. (see: jaime.bojorque @bwk.kuleuven.be

Bosworth, W; Huchon, P; and McClay, K. (2005)-The Red Sea and Gulf of Aden Basin.Journal of Africa Tectonophysics, 209.p115-137.

Brey, GP; and Köhler, T. (1990)- Geothermometry in four phase thermometers and practical assessment of existing thermometers. J Petrol. lherzolites II. New 31: 1353-1378.

Butler, L.W; and Spencer, S. (1999)-Landscap evolution and the preservation of tectonic landform along the northern Yammouneh Fault, Lebanon. In: Smith B.J., Whally W.B. and Warek P.A. (eds), uplift, Erosion and Stability: Perspectives on long-term Landscape development. Geological Society, London, Special Publications, 162, 143-156. 
Butler, L.W; Spencer, S; and Griffiths, H.M. (1997)-Transcurrent fault activity on the Dead Sea Transform in Lebanon and its implications for plate tectonics and seismic hazard. Journal of the Geological Society, London, 154, 757-760.

Butler, L.W. S; Spenser, S. and Grifffiths, H.M. (1998)- The structural response to evolving plate kinematics during transperssion evolution of the Lebanese restraining bend of the Dead Sea Transform.In: Continental Transpressional and Transtensionbal Tectonics. Geological Society, London, Special publications, 135, 81-106.

Camp, V.W. and Roobol, M.J. (1989)- The Arabian continental alkali basalt province: part I. Evolution of Harrat Rahat, Kingdom of Saudi Arabia. Geological Society of America Bulletin, 101, 71-95.

Capan, U.Z; Vidal, P. and Cantagrel, J.M. (1987)-K-Ar-Nd-Sr and Pd isotopic study of Quaternary volcanism in :Karasu valley(Hatay).N. end of Dead Sea Rift zone in SE Turkey. Yerbilimleri Bulletin of Earth. Sciences, Hacettepe University, Ankara, 14, 165-178.

Cetin, H; Guneyli, H. and Meyer, L. (2003)- Paleoseismology of the Palu-Lake Hazarsegment of the East Anatolia Fault Zone, Turkey.Tectonophysics, 374, p.163-197.

Chorowicz, J; DHONT, D; Ammar, O; Rukieh, M.and Bilal, A. (2005)- Tectonics of the Pliocene Homs Basalts (Syria) and implications for the Dead Sea Fault Zone Activity. Journal of the geological Society, London, Vol. 162, 259-271.

Coskun, B. (2004)-Arabian-Anatolian plate movements and related trends in southeast turkey`s Oilfields. Energy Sources, 26, 978-1003.

Dubertret, L. (1933)-Les grandes nappes basaltiques syriennes âge et relation avec la tectonique.Bulletin de la Société Géologique de France, 3, 178-180.

Dubertret, L. (1962)-Carte géologique du Liban, Syrie et bordure des pays voisins, 1 /1000000.Muséum d'Histoire Naturelle, Paris.

Frezzotti, M.L; Andersen, T; Neuman, E.R. and Simonsen, S.L. (2002)- Carbonatite melt CO2 fluid inclusions in mantel xenoliths from Tenerif, Canary Islands: a story of trapping, immiscibility and fluid-rock interaction in the upper mantel.Lithos, 64, 77-96.

Giannerini, G; Campredon, R; Ferraud, G. and Abo Zakhem, B. (1998)- Deformation intraplaques et volcanisme associe :exemple de la plaque arabique au Cenozoique. Bull. Soc.Geol., 6, 683-693.

Girdler, RW. (1990)- The Dead Sea transform fault system.Tectonophysics, 180, 1-13.

Gregoire M. Moine B.N.O ReillyS.Y.Cottin j.y. AND Giret A. (2000)-Trace element residence and partitioning in mantle xenoliths metasomatized by alkaline and carbonate-rich melt (Kergulen Islands, India Ocean).Journal of petrology, 41, 477-509.

Heimann, A; Rojay B. and Toprak, V. (1998)-Neotectonics characteristics of Karasu fault zone, northern continuation of Dead Sea Transform in Anatolia (Turkey).In: Third international Turkish Geological Symposium, Ankara, 99.

Ilani, S. Harlavin, Y. and Trawneh, K et al. (2001)-New K-Ar ages of basalts from the Harrat Ash Shaam volcanic field in Jordan: Implications for the span and duration of the upper-mantle upwelling beneath the western Arabian plate. Geological Society of America, 89, p. 1025-1036.

Ismail, M; Delpech, G; Cottin, J-Y; Grégoire, M; Moine, BN. and Bilal, A. (2008)- Petrological and geochemical constraints on the composition of the lithospheric mantle beneath the Syrian rift, northern part of the arabian polate. In Coltorti M and Grégoire $\mathrm{M}$ (eds) Metasomatism in Oceanic and Continental Lithospheric Mantle. Geol Soc London, Spec. pub. 293: 223-251. 
Juteau, T. (1974)- Les ophiolites de la nappe d'Antalya, Turquie, Thèse d'Etat, Univ Nancy $420 \mathrm{p}$.

King, G. (2004)- Les séismes ne se répètent pas. La recherché, n 380, 44: 45-60

Khair, K; Karakasis, G.F. and Papadimetriou, E.E. (2000)-Seismic zonation of the Dead Sea Transform Fault area.Annali di Geophisica, 43, (1), 61-79.

Kohler, T.P. and Brey, GiP. (1990)-Calcium exchange between olivine and clinopyroxene calibrated as a geothermometer for natural peridotites from 2 to $60 \mathrm{~K}$. bar with applications. Geochim. Cosmochim. Acta., 54, 2375-2388.

Laws, E. and Wilson, M. (1997) Tectonics and magmatism associated with mesozoic passive continental margin development in the Middle-East. J. Geol. Soc.London, 154: 459-464.

Lay, T. and Wallace, J.C. (1995)- Modern Global Seismology. Academic Press, INC. 521p.

Le Bas, M.J; Le Maitre R.W; Streckeisen, A. and Zanettin, B.A. (1986)-Chemical classification of volcanic rocks based on the total alkali-silica diagram.Journal of petrology, 27, 745-750.

Le Béon, M. (2008)- Cinématique d'un segment de faille decrochante à différentes échelles de temps:la faille de Wadi Araba, segment sud de la faille transformante de Levante. Thèse Doctorat, Université Paris VI.

Lovelock, PER. (1984) - A review of the tectonics of the northern Middle East region. Geol Mag 121: 577-587.

Maderiaga, R. (2004)- Chaque seisme est unique. La recherché, n 275.

McLusky, S; Balassanian, S. and Barka, A. et al. (2000)-Global positining system constraints on plate kinematics and dynamics in the eastern Mediterranean and Caucasus.Journal of Geophysical Research, 105, 5695-5719.

Meghraui, M; Gomez, F; Sbeinati, R; Woerd, J.V.D; Mouty, M; AlDarkal, A.N; Radwan, Y; LAYYONS, I; AlNajjjar, H; Darawcheh, R; Hijazi, F; AlGhazzi, R.and Barazangi, M. (2003)-Evidence for 830 years of seismic quiescence from palaeoseismology, archaeology seismology, and historical seismicity along the Dead Sea fault in Syria. Earth and Planetary Science Letters, 210, 35-52.

Molinaro, M; Leturmy, P; Guezou, J.C; Frizon de Lamotte, D. and Eshraghi, S.A. (2005)-The structure and Kinematic of the southeastern Zagros fold-thrust belt, Iran: from thinskinned to thick-skinned tectonics, Tectonics, 24, P.TC3007.

Mor, D. (1993)-A time table for the Levant Volcanic Province, according to K-Ar dating in the Golan heights. J. Afr. Earth Sci., 16, p.223-234.

Mouty, M; Delaloye M; Fontignie D; Piskin, O. and Wagner, J.J. (1992)-The volcanic activity in Syria and Lebanon between Jurassic and Actual. Schweizerische Mineralogische und Petrologische Mitteilungen, 72, 91-105.

Ozkan, M.Y. (1998)-A review of consideration on seismic safety of embankments and earth and rock-fill dams. Soil Dynamic and Earthquake Engineering, 17, 439-458. natol.

Polat, A; Kerrich, R. and Casey, J.F. (1997)-Geochemistry of Quaternary basalts erupted along the East Anatolian and Dead Sea Fault Zone of southern Turkey: Implications for mantle source.Lithos, 40, 55-68.

Parrot, J-P. (1977)- Assemblage ophiolitique du Baer-Bassit et termes effusifs du volcanosédimentaire pétrologique d'un fragment de la croûte océanique téthysienne chariée sur la plateforme syriennne. O.R.S.T.O.M Paris. 72.

Ponikarov, V.P. (1967)-The geological map of Syria, Scale 1/50000, Explanatory notes. Syrian Arab Republic, Ministry of Industry, Damascus.

Robertson, A.H.F; Clift, P.D; Degman, P. and Jones, J. (1991)- Paleoocenography of the Eastern Mediterranean Neotehtys. In: Paleogeography and Paleooceanography of Tethys, Paleogeography, Paleoclimatology, Paleoecology, 87, 289-343. 
Roedder, E. (1984) - Reviews in mineralogy, vol.12, fluid inclusions. Mineralogical Society of America. 645p.

Rojay, B; Heimann, A. and Toprak, V. (2001)-Neotectonic and volcanic charactiristics of the Karasu fault zone (Anatolia, Turkey):The transition between the Dead Sea Transform and the East Anatolian fault zone.Geodynamica Acta, 14, 197-212.

Sawaf, T; Al Saad, D; Gebran, A; Barazangi, M; Best, JA. and Chaimove, T. (1993)- Structure and stratigraphy of eastern Syria across the Euphrate depression. Tectonophysics, 220: 267-281.

Sbeinati, M. and Darawcheh, R. (1992)- seismological bulletin for earthquakes in and around Syria.Report international, SAES, Damascus.

Sharkov, YE.V; Lazko, YE.YE. and Hanna, S. (1993)- Plutonic xenoliths from the Nabi Matta explosive center, Northwest Syria. Geochemistry international, 30, (4). 23-24.

Sharkov, YE.V; Shernyshev, I.V; Devyatkine, V. and al. (1994)- Geochronology of Late Cenozoic basalts in Western Syria.Petrology, 2(4), 439-448.

Sharkov, YE.V; Chernyshev, I.V. and Devyatken E.V. et al. (1998)-New data on the geochronology of upper Cenozoic plateau basalts from the northeastern periphery of the Red Sea rift area(Northern Syria). Doklady Earth Sciences, 358, (1), 19-22.

Shaw, J.E. Baker, J.A. R; Kent, A.J. R; Ibrahim, K.M. and Menzies, M.A. (2007)- The geochemistry of the Arabian lithospheric mantle -a source for intraplate volcanism? Journal of petrology, Vol.48, no 8, 1495-1512.

Sheleh, F. (2001)- Étude des enclaves mantéliques associées au rift syrien; Composition et évolution du manteau supérieur en Syrie-Implications géodynamiques et régionales. Thèse de doctorat (en Arabe), Université de Damas, 180p.

Sosson, M; Rolland, Y; Corsini, M; Danelian, T; Stephan, J-F; Avagyan, A; Melkonian, R;Jrbashyan, R; Melikian, L. and Galoin, G. (2005)-Tectonic evolution of the Lesser Caucasus (Armenia) revisited in the light of new structural and stratigraphical results.European Geosciences Union. Geophysical Research Abstracts, V 7, 06224.

Stein, M. and Hofman, A. (1992)- Fossil plume head beneath the Arabian lithosphere?, Earth Planet. Sci. Let, n 114, 193- 209.

Stein, M; Garfunkel, Z.and Jagoutz, E. (1993) Chronometry of peridotite, pyroxenite xenoliths: implications for the thermal evolution of the arabian plate. Geochim Cosmochim Acta, 57: 1325-1337.

Stiro, S. (1992)- Epicenters of earthquakes from 1961-1983, after USGS.Workshop, Damascus, 32-36

SYRIAN ENGENEERING SYNDICAT, (2004)- The Syrian seismicity code. Damascus, Syria.

Taher, M.A. (1979)- Documents historiques des tremblements de terre en Syrie depuis l'Islam jusqu'à XII siècle "hygerique".Thèse Université, Paris 1, $300 \mathrm{P}$.

UNESCO (1983)- Assessement and mitigation of earthquakes risk in the Arab region. UNESCO/AFESD/IDP.

U.S. Geological Survey (1999)- Special Report:The Hector Mine Earthquake 10/16/99(1999), (see $h t t p / / W w w . S o c a l . W . U s g s . G o v / H e c t o r / R e p o r t / H t m l$ )

Walley, C.D. (1998)-Some outstanding issues in the geology of Lebanon and their importance in the tectonic evolution of the Levantine region.Tectonophysics, 298, 37-62.

Wells, P.R.A. (1977)-Pyroxene thermometry in simple and complex systems. Contr.Mineral.Petrol., 62, 129-139.

Yeats, R.S; Sieh, K. and Allen, C.R. (1997)- The geology of earthquakes. Oxford Univ. Press.

Yurtmen, S; Guillou, H; Westaway, R; Rowbotham, G. and Tatar, O. (2002)-Rate of strik-slip motion on the Amanos Fault(Karasu valley, southern Turkey) constrained by Kr-Ar dating and geochemical analysis of Quaternary basalts.Tectonophysics, 344, 207-246. 


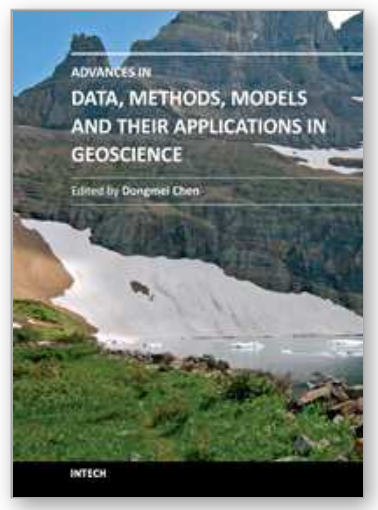

\section{Advances in Data, Methods, Models and Their Applications in Geoscience}

Edited by Dr. DongMei Chen

ISBN 978-953-307-737-6

Hard cover, 336 pages

Publisher InTech

Published online 22, December, 2011

Published in print edition December, 2011

With growing attention on global environmental and climate change, geoscience has experienced rapid change and development in the last three decades. Many new data, methods and modeling techniques have been developed and applied in various aspects of geoscience. The chapters collected in this book present an excellent profile of the current state of various data, analysis methods and modeling techniques, and demonstrate their applications from hydrology, geology and paleogeomorphology, to geophysics, environmental and climate change. The wide range methods and techniques covered in the book include information systems and technology, global position system (GPS), digital sediment core image analysis, fuzzy set theory for hydrology, spatial interpolation, spectral analysis of geophysical data, GIS-based hydrological models, high resolution geological models, 3D sedimentology, change detection from remote sensing, etc. Besides two comprehensive review articles, most chapters focus on in-depth studies of a particular method or technique.

\section{How to reference}

In order to correctly reference this scholarly work, feel free to copy and paste the following:

Ahmad Bilal (2011). Mapping and Analyzing the Volcano-Petrology and Tectono-Seismicity Characteristics Along the Syrian Rift - NW the Arabian Plate, Advances in Data, Methods, Models and Their Applications in Geoscience, Dr. DongMei Chen (Ed.), ISBN: 978-953-307-737-6, InTech, Available from:

http://www.intechopen.com/books/advances-in-data-methods-models-and-their-applications-ingeoscience/mapping-and-analyzing-the-volcano-petrology-and-tectono-seismicity-characteristics-along-thesyrian-

\section{INTECH}

open science | open minds

\section{InTech Europe}

University Campus STeP Ri

Slavka Krautzeka 83/A

51000 Rijeka, Croatia

Phone: +385 (51) 770447

Fax: +385 (51) 686166

www.intechopen.com

\section{InTech China}

Unit 405, Office Block, Hotel Equatorial Shanghai

No.65, Yan An Road (West), Shanghai, 200040, China

中国上海市延安西路 65 号上海国际贵都大饭店办公楼 405 单元

Phone: +86-21-62489820

Fax: $+86-21-62489821$ 
(C) 2011 The Author(s). Licensee IntechOpen. This is an open access article distributed under the terms of the Creative Commons Attribution 3.0 License, which permits unrestricted use, distribution, and reproduction in any medium, provided the original work is properly cited. 